Калічак Юрій Львович кандидат педагогічних наук, доцент кафедри загальної педагогіки та дошкільної освіти, Дрогобицький державний педагогічний університет імені Івана Франка, вул. І. Франка, 24, м. Дрогобич, 82100, тел.: (067) 798-39-88, https://orcid.org/0000-0003-4348-1740

\title{
ФОРМУВАННЯ ЗДОРОВ'ЯЗБЕРЕЖУВАЛЬНОЇ КОМПЕТЕНТНОСТІ ВИХОВАТЕЛІВ ВНАСЛІДОК ВИВЧЕННЯ КУРСУ «ОЗДОРОВЧІ ТЕХНОЛОГІї ТА ДІАГНОСТИЧНІ МЕТОДИКИ ФІЗИЧНОГО РОЗВИТКУ ДІТЕЙ ДОШКІЛЬНОГО ВІКУ»
}

Анотація. У статті на основі детального аналізу психолого-педагогічних джерел досліджено особливості формування здоров'язбережувальної компетентності у вихователів дитячих садків. Обгрунтовано актуальність даної проблеми в сучасній системі дошкільної освіти України.

3'ясовано основні чинники формування здоров'язбережувальної компетентності та необхідність викладання дисципліни «Оздоровчі технології та діагностичні методики фізичного розвитку дітей дошкільного віку» для студентів спеціальності «Дошкільна освіта» у закладах вищої педагогічної освіти.

В статі проаналізовано змістовно-організаційні аспекти формування здоров'язбережувальної компетентності як вважливої складової професійної готовності вихователя закладу дошкільної освіти.

Здоров’язбережувальна компетентність розглядається як інтегральна, динамічна риса особистості, котра полягає в здатності організувати й регулювати оздоровчу діяльність. Здоров'язбережувальна компетентність вихователя забезпечується комплексом професійно орієнтованих знань, умінь, ставлень та цінностей, спрямованих на збереження та зміцнення здоров'я дітей дошкільного віку.

Охарактеризовані напрями в системі професійної підготовки студентівмайбутніх вихователів закладів дошкільної освіти та умови, що забезпечуватимуть реалізацію важливих професійно-орієнтованих завдань формування здоров'язбережувальної компетентності.

Доведено, що підготовка сучасного фахівця дошкільного профілю неможлива без формування в нього уявлень про новітні фізкультурнооздоровчі технології, котрі використовуються в залежності від показників психофізичного розвитку дошкільників, про інноваційну діяльність у сфері фізичного виховання. Особливо це стосується нетрадиційних методів оздоровлення. 


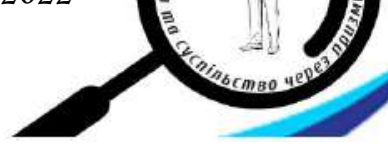

Ключові слова: здоров'язбережувальна компетентність, оздоровчі технології, фахова підготовка, вихователь закладу дошкільної освіти, фахівець дошкільного профілю.

Kalichak Yurii Lvovych Candidate of Pedagogical Sciences, Associate Professor Department of General Pedagogy and Preschool Education Ivan Franko State Pedagogical University in Drohobych, 24, Ivan Franko St., Drohobych, 82100, tel.: (067) 798-39-88, https://orcid.org/0000-0003-4348-1740

\section{FORMATION OF HEALTH-CONTAINING COMPETENCE OF TEACHER OF PRESCHOOL EDUCATION AS A RESULT OF STUDYING THE COURSE «HEALTH TECHNOLOGIES AND DIAGNOSTIC METHODS PHYSICAL DEVELOPMENT OF PRESCHOOL CHILDREN»}

Abstract. The article investigates the peculiarities of formation of healthpreserving competence of pre-school teachers on the basis of a detailed analysis of psychological and pedagogical literary sources. The urgency of this problem in the modern system of preschool education of Ukraine is substantiated.

The main factors of formation of health-preserving competence and the need to teach the discipline "Health technologies and diagnostic methods of physical development of preschool children" to students majoring in "Preschool education" in higher pedagogical education.

The article analyzes the content and organizational aspects of the formation of health competence as an important component of the professional readiness of preschool teachers.

Health competence is seen as an integral dynamic personality trait that manifests itself in the ability to organize and regulate health activities. The healthpreserving competence of a teacher is provided by a set of professionally oriented knowledge, skills, attitudes and values aimed at preserving and strengthening the health of preschool children.

The directions in the system of professional training of preschool teachers and the conditions that will ensure the implementation of important professionallyoriented tasks of forming health-preserving competence are described.

It is proved that the training of a modern specialist of preschool education is impossible without the knowledge about the latest physical culture and health technologies, which are used depending on the indicators of psychophysical development of preschoolers, and innovative activities in the field of physical education. This is especially true of non-traditional healing methods.

Keywords: health-preserving competence, health-improving technologies, professional training, preschool teacher, preschool education specialist. 
Постановка проблеми. Процеси оптимізації системи вищої педагогічної освіти, котрі викликані сучасним соціальним замовленням, мають на меті забезпечення закладів дошкільної освіти високо кваліфікованими педагогічними кадрами дошкільного профілю. Сучасні інноваційні методи едукації дітей дошкільного віку диктують вимоги щодо функціонування системи дошкільної освіти загалом, регламентують спрямованість освітнього процесу в дитячому садку на основі застосування здоров'язбережувальних технологій зокрема. Поліпшення фізичного розвитку й фізичної підготовленості дошкільників на сьогодні потребує урізноманітнення й постійного вдосконалення форм та методів діяльності. Задля вирішення окреслених завдань вихователь повинен опанувати різноманітні методики визначення рівня об'єктивного фізичного стану дитини, а також традиційні та нетрадиційні оздоровчі технології.

Аналіз останніх досліджень. Останнім часом у фізичному розвитку найменших громадян України спостерігається стійка тенденція до відчутного зниження щоденної рухової активності та, як наслідок, суттєві відхилення здоров'я ослабленої дитини (слабкість нервово-м'язового апарату, погіршення роботи функціональних систем організму, погіршення інтелектуальної та фізичної працездатності, швидка втомлюваність тощо).

Однією з основних причин дитячих хвороб вважаємо недостатність або повна відсутність оздоровчої спрямованості освітнього процесу загалом та 3 фізичного виховання зокрема. Значна частина закладів дошкільної освіти не використовують відповідні форми роботи з фізичного виховання дітей з метою досягнення фізичної досконалості (формування міцного здоров'я, гармонійного фізичного розвитку, рухової підготовленості, розвитку основних локомоцій і фізичних якостей), а лише дбають про стандартний набір рухових дій чи наявність певної кількості рухів чи рухових дій.

Модернізація освітньої діяльності має на меті створення сприятливих умов задля зміцнення здоров'я малюків через широке застосування різноманітних здоров'язбережувальних технологій в дошкільній освіті.

Оздоровчі заходи лише тоді приноситимуть користь, коли дошкільник із задоволенням дотримуватиметься всіх рекомендації та організаційнометодичних вказівок.

Майстерність сучасного вихователя полягає не лише у досконалому опануванні теоретичними знаннями, але й у здатності запроваджувати прогресивні ідеї та оздоровчі технології у практику, займатися інноваційною діяльністю в галузі здоров'язбереження дітей дошкільного віку. Сприятиме такій діяльності, насамперед, створення належного предметно-ігрового розвивального середовища, а також комфортних умов для перебування дітей у дитячому садку тощо [10].

Саме тому існує нагальна потреба індивідуалізації занять фізичними вправами, зокрема використання загальнорозвивальних й оздоровчих 


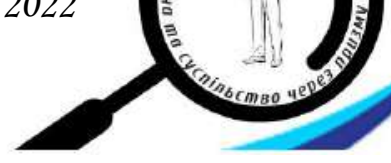

комплексів, котрі б сприяли формуванню основних локомоцій i розвитку рухових якостей вже змалку в дітей дошкільного віку.

Правильний підбір індивідуальних корекційно-оздоровчих технологій, здійснення систематичних тестувань задля отримання інформації про динаміку психофізичного стану дошкільника дозволить успішно здійснювати необхідну корекції тренувальних програм.

Аналіз психолого-педагогічної літератури щодо фахової підготовки фахівців з фізичної культури свідчить про наявність різних аспектів цієї проблеми, зокрема: вдосконалення професійної підготовки фахівців 3 фізичної культури (М. Т. Данилко, М. Д. Зубалій, Т. Г. Овчаренко, Б. М. Шиян та ін.); формування індивідуальних здібностей студентів у процесі навчання та виховання (В. М. Марищук, В. С. Фарфель); упровадження особистісно орієнтованих технологій навчання та виховання у закладах вищої педагогічної освіти (I. Д. Бех, О. О. Вербицький, Л. П. Сущенко); психолого-педагогічні основи навчання майбутніх вихователів (О. В. Федик, А. В. Цьось та ін); підготовка студентів до фізичного виховання дошкільників (О. Л. Богініч, Л. В. Волков, Н. Ф. Денисенко, 3. І. Нестерова, Т. І. Поніманська, Л. А. Рижова) [1-8; 13-17].

Однак конкретних рекомендацій щодо діагностики стану здоров’я дітей та здійснення фізичного розвитку з урахуванням наявних відхилень не знаходимо. Саме відсутність чіткого й конкретно обгрунтованого змісту фахової підготовки вихователя, а також належних форм і методів його реалізації диктує необхідність вивчення навчальної дисципліни «Оздоровчі технології та діагностичні методики фізичного розвитку дітей дошкільного віку».

Мета курсу, на наш погляд, передбачає ознайомлення студентів із відповідними інноваційними, нестандартними, нетрадиційними підходами щодо здійснення фізичного розвитку дітей дошкільного віку та 3 основними методиками його діагностики, котрі уможливлюють оцінку їх фізичного стану. Даний курс є своєрідним продовженням дисципліни «Методика фізичного виховання та валеологічної освіти дітей дошкільного віку» та дозволяє узагальнити набуті знання 3 різних галузей науки (анатомії, фізіології, педагогіки, психології тощо) задля створення єдиного здоров’ язбережувального середовища у сучасних закладах дошкільної освіти [12].

Мета статті - 3'ясувати можливості поліпшення процесу підготовки вихователів до організації та здійснення індивідуалізованого фізичного розвитку дітей дошкільного віку.

Виклад основного матеріалу. Програма курсу «Оздоровчі технології i діагностичні методики фізичного розвитку дітей дошкільного віку» розрахована на 90 годин (кількість кредитів відповідно до ECTS - 3). Теоретичний блок - 16, практичний - 32, самостійна робота - 42 годин [12, с. 1].

Основні компетентності, котрі повинні засвоїти вихователі:

- творчо «використовувати отримані знання з методики фізичного виховання дітей при вирішенні навчально-виховних завдань у роботі з дошкільниками; 
- володіти основами методики проведення різноманітних фізкультурнооздоровчих заходів у режимі дня закладу дошкільної освіти;

• розробляти та втілювати нові організаційно-педагогічні нетрадиційні форми, методи оздоровлення дошкільників (з урахуванням побажань батьків);

- організовувати раціональне предметне середовище для різних форм, видів рухової активності,;

-створювати сприятливі умови для позитивних емоційних та моральновольових проявів дітей;

- залучати батьків до активної участі в навчально-оздоровчій роботі;

- враховувати вікові та індивідуальні особливості дітей дошкільного віку в процесі проведення занять з фізичного виховання;

• орієнтуватись у спеціальній науково-педагогічній літературі відповідно до профілю підготовки.

• вивчати, аналізувати й оцінювати рівень фізичного розвитку дітей дошкільного віку;

- планувати та проводити оздоровчі заходи у режимі дня закладу дошкільної освіти;

• враховувати у своїй діяльності психолого-педагогічні основи організації фізкультурно- оздоровчих занять;

-складати індивідуальну програму оздоровлення організму дошкільника» [12, с. 2].

Програмовий зміст навчальної дисципліни передбачає таку тематику: «Предмет вивчення та основні поняття курсу «Оздоровчі технології та діагностичні методики фізичного розвитку дітей дошкільного віку». Нестандартні методики та технології фізичного розвитку дітей дошкільників у сучасних умовах. Оздоровлення дітей дошкільного віку. Оздоровлення дітей з особливими потребами. Оздоровчі види гімнастики. Масаж. Формування правильної постави та профілактика плоскостопості у дітей дошкільного віку» [12, с. 3].

Зазначений зміст уможливить опанування вихователями закладів дошкільної освіти конкретними методиками оцінки фізичного стану дитини й сприятиме створенню конкретних умов реалізації принципу «індивідуалізації та оздоровчої спрямованості педагогічних впливів у фізичному вихованні дітей дошкільного віку» $[12$, с. 2].

Серед інших звернемо увагу на «авторські методики (система фізичного виховання П. Ф. Лесгафта, Вальдорфська педагогіка Рудольфа Штайнера, методика Марії Монтессорі, система фізичного виховання дітей сім’і Нікітіних, система загартування П. К. Іванова «Дєтка», система формування рухових навичок дітей Глена Домана, фізичний розвиток дитини за методикою Сесіль Лупан тощо)», а також на окремі найбільш характерні на сьогодні теми: «Етнопедагогічні оздоровчі технології. Традиції української етнопедагогіки щодо виховання здорової дитини. Інноваційна діяльність в галузі фізичного 
виховання дошкільників. Загальна характеристика інноваційних оздоровчих технологій. Технології психофізичного розвитку дошкільників» [12, с. 5].

Рівень фізичного розвиту $є$ важливим показником комплексної оцінки здоров'я дошкільників, котрий обов'язково враховують під час визначення групи здоров'я дошкільника. Студентам необхідно знати ці критерії, а саме: «особливості стану здоров'я i фізичного розвитку кожної дитини, яке проводиться у дошкільному навчальному закладі під час медичних оглядів дітей. На основі цих даних 3 урахуванням висновків лікарів за місцем проживання, лікування, медичного консультування дітей, лікар і медична сестра дошкільного закладу розподіляють вихованців за медичними групами (групами здоров’я), фіксують висновки і рекомендації щодо участі дітей у фізкультурно-оздоровчих заходах, формах освітньої роботи 3 фізичного розвитку і виховання в індивідуальних медичних картках та доводять їх до відома батьків вихованців і педагогів. Залежно від встановленої медичної групи та індивідуальних призначень вихователі, інструктори 3 фізичної культури і плавання забезпечують відповідний ступінь участі кожної дитини в системі фізкультурно-оздоровчої роботи, оптимальний рівень фізичних, психічних, емоційних навантажень для неї» [11, с. 9].

Серед найбільш розповсюджених форм організації здоров'язбережувальної діяльності сучасного закладу дошкільної освіти відзначимо такі: «заняття з фізичного розвитку, самостійну рухову діяльність дітей, рухливі ігри, ранкова гімнастика, оздоровчі фізкультурні хвилинки, фізичні вправи після денного сну, фізичні вправи в поєднанні 3 загартувальними процедурами, фізкультурні прогулянки, фізкультурне дозвілля, спортивні свята, різноманітні естафети та змагання, оздоровчі процедури у воді тощо» [17, с. 5].

Нині активно впроваджуються новітні види оздоровчої діяльності, зокрема «оздоровчо-розвивальні хвилинки, стимулювальна гімнастика, імунна гімнастика, психогімнастика (вправи, ігри тощо), арт-гімнастика, кольоротерапія, казкотерапія, сміхотерапія, сольова підлога, фітболгімнастика, художня гімнастика, гідроаеробіка, дитячий фітнес» [5, с. 3].

Використання новітніх інноваційних розвивальних технологій 3 метою поліпшення фізичного стану дошкільників повинно уможливити досягнення оздоровчого та розвивального ефекту за умови відсутності негативних наслідків для організму дитини. Доцільність застосування подібних технологій передбачає знання різноманітних методик діагностики рівня фізичного розвитку, як основного показника в комплексній оцінці стану здоров'я малюка. 3 цією метою студенти повинні опанувати такі морфометричними методи визначення головних критеріїв фізичного розвитку:

- антропометрія (вимірювання окружності грудної клітини; довжини та маси тіла, а також коефіцієнтами, що дозволяють судити про пропорційність розвитку: індекс повноти, індекси Ерісмана, Піньє тощо; 
-функціональними (частота серцевих скорочень, артеріальний тиск, реакція організму на фізичне навантаження), а також 3 методиками соматотипування (метод оцінки динамічного соматотипу за У. Шелдоном та метод визначення соматотипів на основі величин сигнальних відхилень довжини, маси тіла та окружності грудної клітини від середньоарифметичних за І. Бахрак) [7, с. 3].

Міцні знання закономірностей швидкоплинних змін в організмі дошкільників, котрі продиктовані швидким ростом, розвитком та цілеспрямованими та заздалегідь спланованими заняттями фізичними вправами, дозволять фахівцям не лише адекватно реагувати на закономірні адаптивні й вікові зміни, але й усувати наявні несприятливі стани, котрі спровоковані використанням невластивих форм фізкультурно-оздоровчих занять (невідповідність навантаження фізичній підготовленості дошкільника, індивідуальні особливості малюків тощо).

Міністерство освіти i науки України у Інструктивно-методичних рекомендаціях «Організація фізкультурно-оздоровчої роботи у дошкільних навчальних закладах» визначило пріоритетні напрями використання традиційних i нетрадиційних методів оздоровлення малюків та практичні можливості їх втілення у практику роботи сучасних закладів дошкільної освіти. Відтак, сучасний фахівець має опанувати цілий арсенал оздоровчих технологій. «Поряд 3 традиційними засобами фізичного виховання, оздоровлення дошкільників у практиці роботи дошкільних закладів знаходять місце інші. Наприклад: фітбол-гімнастика - вправи з використанням м'яча, що має певні властивості (розмір, колір, запах, пружність), які застосовуються 3 оздоровчою метою; стретчинг - система вправ, заснована на статичних розтягненнях м'язів тіла і хребта, яка дає змогу запобігати порушенню постави, має оздоровчий вплив на весь організм, допомагає активізувати його захисні сили; горизонтальний пластичний балет - система партерних рухів, що виконуються у горизонтальних вихідних положеннях від положення лежачи у позі ембріона до положення стоячи на колінах, повільно і плавно, у супроводі класичної і сучасної музики у формі цілісних композицій» [11, с. 3].

Діяльність теперішнього дитячого садка закцентована на зміцненні психофізичного здоров'я дитини, що неможливе без здійснення інноваційної діяльності у сфері фізичного виховання. Особливо це стосується нетрадиційних методів оздоровлення. Звідси існує нагальна потреба засвоєння студентами фізичної та психологічної спрямованістю нетрадиційних оздоровчих методик (наприклад, різноманітні види дихальних гімнастик тощо).

До робочої програми дисципліни «Оздоровчі технології і діагностичні методики фізичного розвитку дітей дошкільного віку», на наш погляд, варто включати інноваційні технології, котрі одночасно вирішують завдання фізичного й нервово-психічного розвитку дітей дошкільного віку (наприклад, технологія фізичного виховання М. Єфименка тощо) 
Висновки. Творчий підхід до організації всіх форм фізкультурнооздоровчої роботи, постійний обмін передовим досвідом дозволять забезпечити вихователям закладів дошкільної освіти успіх у фізичному вихованні дітей. Однак вирішальним завжди залишатиметься високий рівень здоров'язбережувальної компетентності.

Відчутному зниженню захворюваності дітей дошкільного віку сприятиме грунтовне опанування оздоровчих систем студентами закладів вищої педагогічної освіти, педагогічними працівниками ЗДО.

Сучасна система підготовки фахівця дошкільного профілю неможлива без формування в нього уявлень про фізкультурно-оздоровчі технології, котрі необхідно застосовувати згідно 3 показниками фізичного й морфофункціонального розвитку дошкільників. Необхідний обсяг знань у галузі здоров'язбереження студенти мають можливість опанувати упродовж вивчення навчальної дисципліни «Оздоровчі технології та діагностичні методики фізичного розвитку дітей дошкільного віку».

Перспективи подальших пошуків у напрямку дослідження полягають у відчутному збагаченні змісту навчальних програм педагогічних вишів у таких напрямках: технології формування культури здоров'я дітей дошкільного віку, засвоєння знань щодо здорового способу життя дошкільників, організація дієвого здоров’ язбережувального середовища в закладі дошкільної освіти.

\section{Jimepamypa:}

1. Букреєва Н. М. Створення здоров'язбережувального середовища в дошкільному закладі (за результатами експериментальної роботи). Запоріжжя. ТОВ «ЛІПС» ЛТД, 2007. № 3. С. 54-61.

2. Вільчковський Е. С. Організація рухового режиму дітей у дошкільних навчальних закладах: навчально-методичний посібник. Тернопіль: Мандрівець, 2008. 128 с.

3. Вільчковський Е. С., Курок О. І. Теорія і методика фізичного виховання дітей дошкільного віку: навчальний посібик Суми: ВТД «Університетська книга», 2004. 428 с.

4. Воронцова Т. В. Навчання здоровому способу життя на основі життєвих навичок: монографія. Київ: Просвіта, 2007. 246 с.

5. Григоренко Г. І., Денисенко Н. Ф., Коваленко Ю. О., Маковецька Н. В. Нетрадиційні методи оздоровлення дітей дошкільного віку: навч. посібник. Запоріжжя: ЗНУ, 2006. 116 с.

6. Григоренко Г. І., Денисенко Н. Ф., Коваленко Ю. О., Маковецька Н. В. Оздоровча робота в дошкільному навчальному закладі: навчальний посібник Запоріжжя: ЗНУ, 2006. С. 99.

7. Денисенко Н. Ф. Оздоровчі технології в освітньому процесі. Дочкільне виховання 2004. № 12. С. 4-6.

8. Денисенко Н. Ф. Освітній процес має бути здоров'язбережувальним. Дошкільне виховання. 2007. № 7. С. 8-10.

9. Загородня Л. П., Тітаренко С. А., Барсуковська Г. П. Фізичне виховання дітей дошкільного віку: навчальний посібник. Суми: Університетська книга, 2018. 272 с.

10. Загородня Л. П. Педагогічна майстерність вихователя дошкільного закладу: монографія. Суми : «Університетська книга», 2010. 319 с.

11. Інструктивно-методичні рекомендації «Організація фізкультурно-оздоровчої роботи у дошкільних навчальних закладах». Режим доступу: https://imzo.gov.ua/2016/09/08/ 
list-mon-vid-02-09-2016-1-9-456-shhodo-organizatsiyi-fizkulturno-ozdorovchoyi-roboti-udoshkilnih-navchalnih-zakladah/.

12. Калічак Ю. Л. Оздоровчі технології та діагностичні методики фізичного розвитку дітей дошкільного віку: робоча програма. Дрогобич: Редакційно-видавничий відділ Дрогобицького державного педагогічного університету імені Івана Франка, 2017. 12 с.

13. Комісарик М. І., Чуйко Г. В. Теорія та методика фізичного виховання дітей дошкільного віку: підручник. Чернівці. Книги-XXI, 2013. 484 с.

14. Організація оздоровчої роботи в дошкільному навчальному закладі: укл. Л. А. Швайка. Харків: Основа, 2008. 253 с.

15. Оржеховська В. М. Здоров'язберігаюче навчання й виховання. Наукові записки Ніжинського державного університету імені Миколи Гоголя. 2008. № 1. С. 24-28.

16. Рубан Н. Здоров'ятворчі та здоров'язбережувальні технології. Палітра педагога. 2010. № 2. С. 2-6.

17. Шамрай А. I. Організація фізкультурно-оздоровчої роботи в дошкільному навчальному закладі. Дошкільний навчальний заклад. 2007. № 10. С. 8-10.

\section{References:}

1. Bukreeva N. M. Stvorennya zdorov"yazberezhuval'noho seredovyshcha v doshkil'nomu zakladi (za rezul'tatamy eksperymental'noyi roboty). [Creating a healthy environment in preschool (according to the results of experimental work) ]. Zaporizhzhia. LIPS LTD, 2007. № 3. P. 54-61 [in Ukrainian].

2. Vilchkovsky E. S. Orhanizatsiya rukhovoho rezhymu ditey u doshkil'nykh navchal'nykh zakladakh: navchal'no-metodychnyy posibnyk. [Organization of the motor regime of children in preschool educational institutions: a textbook]. Ternopil: Mandrivets, 2008. 128 p. [in Ukrainian].

3. Vilchkovsky E. S., Kurok O. I. Teoriya i metodyka fizychnoho vykhovannya ditey doshkil'noho viku: navchal'nyy posibyk. [Theory and methods of physical education of preschool children: a textbook]. Sumy: VTD "University Book", 2004. 428 p. [in Ukrainian].

4. Vorontsova T. V. Navchannya zdorovomu sposobu zhyttya na osnovi zhyttyevykh navychok: monohrafiya. [Learning a healthy lifestyle based on life skills: a monograph]. Kyiv: Prosvita, 2007. 246 p. [in Ukrainian].

5. Grigorenko G. I., Denisenko N. F., Kovalenko Y. O., Makovetskaya N. V. Netradytsiyni metody ozdorovlennya ditey doshkil'noho viku: navch. posib. [Non-traditional methods of improving the health of preschool children: textbook. way]. Zaporozhye: ZNU, 2006. 116 p. [in Ukrainian].

6. Grigorenko G. I., Denisenko N. F., Kovalenko Y. O., Makovetskaya N. V. Ozdorovcha robota $\mathrm{v}$ doshkil'nomu navchal'nomu zakladi: navch. posib. [Health-improving work in preschool educational institution: textbook. way]. Zaporozhye: ZNU, 2006. P. 99. [in Ukrainian].

7. Denisenko N. F. Ozdorovchi tekhnolohiyi v osvitn'omu protsesi. [Health technologies in the educational process]. Doshkil'ne vykhovannya. - Preschool education. 2004. № 12. S. 4-6. [in Ukrainian].

8. Denisenko N. F. Osvitniy protses maye buty zdorov"yazberezhuval'nym. [The educational process must be healthy]. Doshkil'ne vykhovannya. - Preschool education. 2007. № 7. S. 8-10. [in Ukrainian].

9. Zagorodnya L. P., Titarenko S. A., Barsukovskaya G. P. Fizychne vykhovannya ditey doshkil'noho viku: navchal'nyy posibnyk. [Physical education of preschool children: a textbook]. Sumy: University Book, 2018. 272 p. [in Ukrainian].

10. Zagorodnya L. P. Pedahohichna maysternist' vykhovatelya doshkil'noho zakladu: monohrafiya. [Pedagogical skill of the preschool teacher: monograph]. Sumy: "University Book", 2010. 319 p. [in Ukrainian]. 
11. Instruktyvno-metodychni rekomendatsiyi «Orhanizatsiya fizkul'turno-ozdorovchoyi roboty u doshkil'nykh navchal'nykh zakladakh». [Instructional and methodical recommendations "Organization of physical culture and health work in preschool educational institutions"]. Access mode: https://imzo.gov.ua/2016/09/08/list-mon-vid-02-09-2016-1-9-456-shhodo-organizatsiyifizkulturno-ozdorovchoyi-roboti-u-doshkilne -navchalnih-zakladah /. [in Ukrainian].

12. Kalichak Yu. L. Ozdorovchi tekhnolohiyi ta diahnostychni metodyky fizychnoho rozvytku ditey doshkil'noho viku: robocha prohrama. [Health-improving technologies and diagnostic methods of physical development of preschool children: working program]. Drohobych: Editorial and Publishing Department of Drohobych State Pedagogical University named after Ivan Franko, 2017. 12 p. [in Ukrainian].

13. Commisaryk M. I., Chuiko G. V. Teoriya ta metodyka fizychnoho vykhovannya ditey doshkil'noho viku: pidruchnyk. [Theory and methods of physical education of preschool children: a textbook]. Chernivtsi. Books - XXI, 2013. 484 p. [in Ukrainian].

14. Orhanizatsiya ozdorovchoyi roboty $\mathrm{v}$ doshkil'nomu navchal'nomu zakladi: ukl. L. A. Shvayka. [Organization of health work in a preschool educational institution: incl. L. A. Schweik]. Kharkiv: Osnova, 2008. 253 p. [in Ukrainian].

15. Orzhekhovskaya V. M. Zdorov"yazberihayuche navchannya y vykhovannya. [Healthpreserving education and upbringing.]. Naukovi zapysky Nizhyns'koho derzhavnoho universytetu imeni Mykoly Hoholya - Scientific notes of Mykola Gogol Nizhyn State University. 2008. № 1. S.24-28. [in Ukrainian].

16. Ruban N. Zdorov"yatvorchi ta zdorov"yazberezhuval'ni tekhnolohiyi. [Health and health technologies]. Palitra pedahoha - Teacher's palette. 2010. № 2. S. 2-6. [in Ukrainian].

17. Shamrai A. I. Orhanizatsiya fizkul'turno-ozdorovchoyi roboty v doshkil'nomu navchal'nomu zakladi. [Organization of physical culture and health work in preschool education]. Doshkil'nyy navchal'nyy zaklad - Preschool educational institution. 2007. № 10. S. 8-10. [in Ukrainian]. 